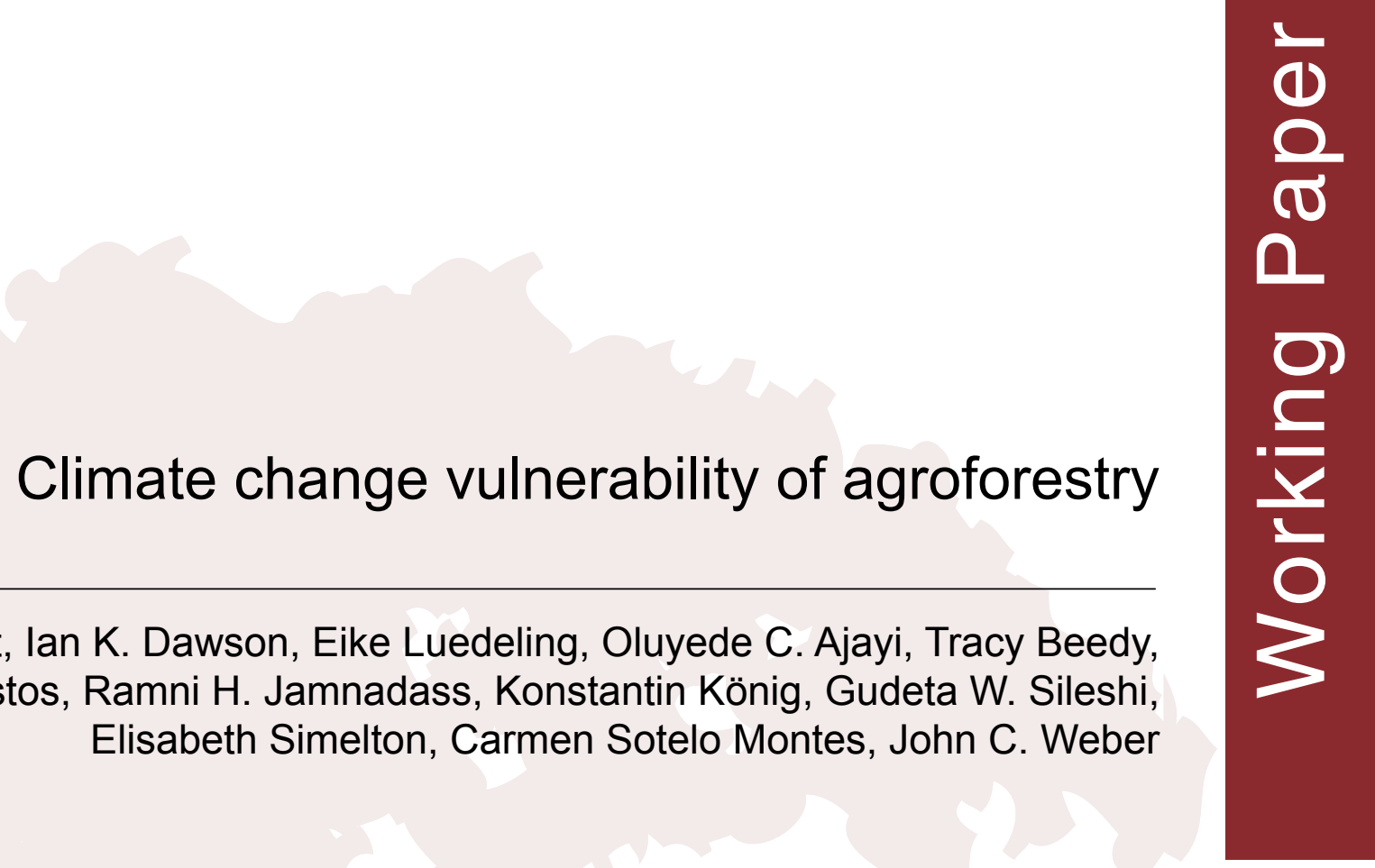

Henry Neufeldt, Ian K. Dawson, Eike Luedeling, Oluyede C. Ajayi, Tracy Beedy, Aster Gebrekirstos, Ramni H. Jamnadass, Konstantin König, Gudeta W. Sileshi, Elisabeth Simelton, Carmen Sotelo Montes, John C. Weber 


\section{Climate change vulnerability of agroforestry}

Henry Neufeldt, Ian K. Dawson, Eike Luedeling, Oluyede C. Ajayi, Tracy Beedy, Aster Gebrekirstos, Ramni H. Jamnadass, Konstantin König, Gudeta W. Sileshi, Elisabeth Simelton, Carmen Sotelo Montes, John C. Weber

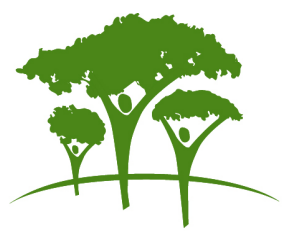




\section{LIMITED CIRCULATION}

World Agroforestry Centre

TRANSFORMING LIVES AND LANDSCAPES

Correct citation: Neufeldt H, Dawson IK, Luedeling E, Ajayi OC, Beedy T, Gebrekirstos A, Jamnadass RH, König K, Sileshi GW, Simelton E, Montes CS, Weber JC. 2012 Climate change vulnerability of agroforestry. ICRAF Working Paper No 143. Nairobi: World Agroforestry Centre http://dx.doi.org/10.5716/WP12013.PDF

Titles in the Working Paper Series aim to disseminate interim results on agroforestry research and practices and stimulate feedback from the scientific community. Other publication series from the World Agroforestry Centre include Technical Manuals, Occasional Papers and the Trees for Change series.

Published by the World Agroforestry Centre

United Nations Avenue

PO Box 30677, GPO 00100

Nairobi, Kenya

Tel: $+254(0) 207224000$, via USA +1 6508336645

Fax: $+254(0) 207224001$, via USA +1 6508336646

Email: worldagroforestry@cgiar.org

Website: www.worldagroforestry.org

(C) World Agroforestry Centre 2012 Working Paper No. 143

The views expressed in this publication are those of the author(s) and not necessarily those of the World Agroforestry Centre.

Articles appearing in this publication may be quoted or reproduced without charge, provided the source is acknowledged. No use of this publication may be made for resale or other commercial purposes.

All images remain the sole property of their source and may not be used for any purpose without written permission from the source.

The geographic designation employed and the presentation of material in this publication do not imply the expression of an opinion whatsoever on the part of the World Agroforestry Centre concerning the legal status of any country, territory, city or area or its authorities, or concerning the delimitation of its frontiers or boundaries. 


\section{TABLE OF CONTENTS}

The importance of agroforestry for food and nutrition security ....................................................... 1

The value of tree commodity crops for smallholders: exploring export trade data ............................. 3

Harvesting and cultivating tree foods to support nutrition .............................................................. 5

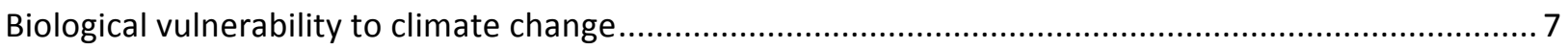

Constraints to projecting climate change impacts on agroforestry systems ..................................... 7

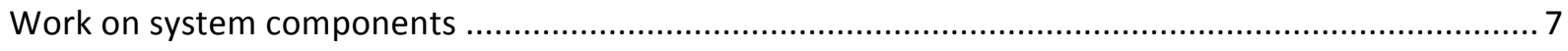

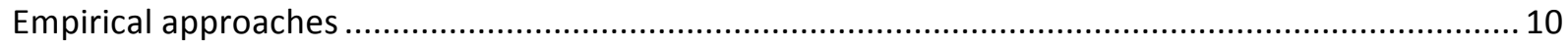

Uncovering past responses on trees to understand the impacts of climate change ........................... 13

Using information from genetic trials and studies in natural populations in climate change adaptation

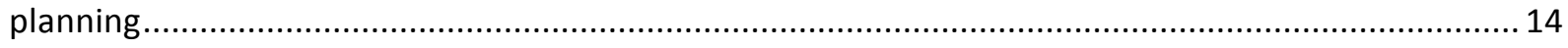

Socioeconomic vulnerability of agroforestry to climate change ......................................................... 15

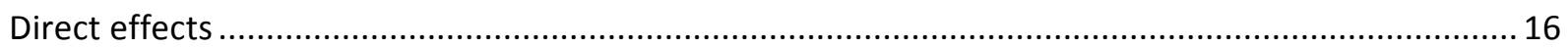

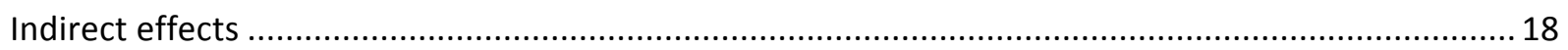

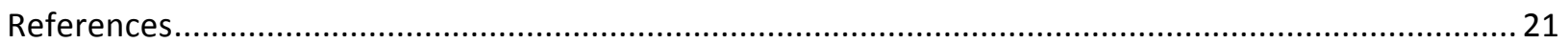




\section{LIST OF ABBREVIATIONS}

$\begin{array}{ll}\text { AFSP } & \text { Agroforestry Food Security Program } \\ \text { AFTD } & \text { Agroforestree Database } \\ \text { AIDS } & \text { Acquired Immune Deficiency Syndrome } \\ \text { ENSO } & \text { El Niño/La Niña-Southern Oscillation } \\ \text { FAO } & \text { Food Agriculture Organization of the United Nations } \\ \text { GAM } & \text { Generalized Additive Model } \\ \text { GCM } & \text { General Circulation Model } \\ \text { HGSF } & \text { Home-grown School Feeding } \\ \text { HIV } & \text { Human Immunodeficiency Virus } \\ \text { ICRAF } & \text { World Agroforestry Centre } \\ \text { IPCC } & \text { Intergovernmental Panel on Climate Change } \\ \text { NEPAD } & \text { New Partnership for Africa's Development } \\ \text { NGO } & \text { Non-governmental Organization } \\ \text { NWFP } & \text { Non-wood Forest Products } \\ \text { PPm } & \text { parts per million } \\ \text { PROSEA } & \text { Plant Resources of South East Asia } \\ \text { PROTA } & \text { Plant Resources of Tropical Africa } \\ \text { RUE } & \text { Rain Use Efficiency } \\ \text { SRES } & \text { Special Report on Emissions Scenarios } \\ \text { UNICEF } & \text { United Nations Children's Fund } \\ \text { USD } & \text { United States Dollar } \\ \text { VECEA } & \text { Vegetation and Climate change in Eastern Africa } \\ \text { WHO } & \text { World Health Organization } \\ \text { WUE } & \text { Water Use Efficiency } \\ & \end{array}$




\section{THE IMPORTANCE OF AGROFORESTRY FOR FOOD AND NUTRITION SECURITY}

Providing a detailed picture of the values of trees for local people in the tropics is a difficult undertaking. Not only does this represent the difficulty in accounting for values outside formal markets, but it also reflects the multiplicity of the species involved and the many different ways in which trees are used. In these circumstances, one approach that can be used to gain insight is to focus on a narrower range of species such as tree commodity crops commonly grown by smallholders, where more data on economic value are available. Another method that can be employed to provide an overview of uses is to search and summarize information from online databases, such as the Plant Resources of Tropical Africa (PROTA, www.prota.org/), the Plant Resources of South-East Asia (PROSEA, www.proseanet.org/prosea/) and the CABI Forest Compendium (www.cabi.org/fc/).

Here, the application of online databases for providing information is demonstrated by considering another resource, ICRAF's open access Agroforestree Database (AFTD, www.worldagroforestry.org/resources/databases/agroforestree). This provides data on 650 tree species that are of interest for both planting and wild harvesting by local communities throughout the tropics. The database includes information on where species grow, how they can be propagated and managed, domestication history, their uses, pests and diseases problems, and a comprehensive bibliography of information sources. In addition, socio-economic data, such as the extent of cultivation by smallholders and the costs and returns of production, are included for a subset of species. The authors undertook a meta-analysis of the database that involved stratifying the information it contained by function, origin of the tree and the geographic region of use (Table 1).

The analysis was based on 10 important tree functions and six geographic regions. Compilation revealed that the most frequent use listed in the AFTD was for timber production, followed by medicine and then fuel (primarily woodfuel). Many species were indicated to have multiple uses, based on the number of mentions summed across functions in any one region (e.g., > 2700 for Africa) compared to the total number of species in the database. Results indicated that local people in large parts of the tropics rely on a wide range of both indigenous and exotic tree species, overall in approximately equal proportions, to meet their needs for various products and services. 
Table 1: The number of tree species mentioned in the Agroforestree Database as providing various functions ${ }^{1}$ in different regions ${ }^{2}$ of the tropics

\begin{tabular}{|c|c|c|c|c|c|c|c|c|}
\hline \multirow[b]{2}{*}{ Function $^{1}$} & \multirow[b]{2}{*}{ Origin } & \multicolumn{7}{|l|}{ Region $^{2}$} \\
\hline & & Africa & Oceania & $\begin{array}{l}\text { South } \\
\text { America }\end{array}$ & $\begin{array}{l}\text { South } \\
\text { Central } \\
\text { Asia }\end{array}$ & $\begin{array}{l}\text { South East } \\
\text { Asia }\end{array}$ & $\begin{array}{l}\text { Western } \\
\text { Asia and } \\
\text { Middle East }\end{array}$ & $\begin{array}{l}\text { Sum } 6 \\
\text { regions }\end{array}$ \\
\hline \multirow[t]{3}{*}{ Apiculture } & E & 89 & 58 & 51 & 74 & 75 & 18 & 365 \\
\hline & I & 88 & 26 & 32 & 34 & 46 & 16 & 242 \\
\hline & $E+I$ & 177 & 84 & 83 & 108 & 121 & 34 & 607 \\
\hline \multirow[t]{3}{*}{ Erosion control } & E & 81 & 50 & 34 & 63 & 61 & 15 & 304 \\
\hline & I & 94 & 20 & 23 & 57 & 56 & 17 & 267 \\
\hline & $\mathrm{E}+\mathrm{I}$ & 175 & 70 & 57 & 120 & 117 & 32 & 571 \\
\hline \multirow[t]{3}{*}{ Fibre } & E & 85 & 58 & 40 & 73 & 82 & 14 & 352 \\
\hline & I & 56 & 35 & 20 & 60 & 67 & 18 & 256 \\
\hline & $E+I$ & 141 & 93 & 60 & 133 & 149 & 32 & 608 \\
\hline \multirow[t]{3}{*}{ Fodder } & E & 134 & 71 & 53 & 105 & 102 & 26 & 491 \\
\hline & I & 161 & 30 & 43 & 112 & 89 & 35 & 470 \\
\hline & $E+I$ & 295 & 101 & 96 & 217 & 191 & 61 & 961 \\
\hline \multirow[t]{3}{*}{ Food } & E & 137 & 81 & 68 & 113 & 115 & 28 & 542 \\
\hline & I & 158 & 43 & 51 & 107 & 110 & 34 & 503 \\
\hline & $\mathrm{E}+\mathrm{I}$ & 295 & 124 & 119 & 220 & 225 & 62 & 1045 \\
\hline \multirow[t]{3}{*}{ Fuel } & E & 167 & 96 & 73 & 133 & 133 & 27 & 629 \\
\hline & I & 190 & 51 & 53 & 110 & 116 & 35 & 555 \\
\hline & $E+I$ & 357 & 147 & 126 & 243 & 249 & 62 & 1184 \\
\hline \multirow[t]{3}{*}{ Medicine } & E & 167 & 101 & 86 & 149 & 158 & 30 & 691 \\
\hline & I & 223 & 58 & 58 & 149 & 156 & 37 & 681 \\
\hline & $\mathrm{E}+\mathrm{I}$ & 390 & 159 & 144 & 298 & 314 & 67 & 1372 \\
\hline \multirow[t]{3}{*}{ Shade/shelter } & E & 139 & 78 & 60 & 109 & 105 & 20 & 511 \\
\hline & I & 142 & 53 & 44 & 84 & 97 & 26 & 446 \\
\hline & $\mathrm{E}+\mathrm{I}$ & 281 & 131 & 104 & 193 & 202 & 46 & 957 \\
\hline \multirow[t]{3}{*}{ Soil improvement } & E & 95 & 56 & 40 & 83 & 84 & 14 & 372 \\
\hline & I & 99 & 27 & 33 & 60 & 70 & 12 & 301 \\
\hline & $E+I$ & 194 & 83 & 73 & 143 & 154 & 26 & 673 \\
\hline \multirow[t]{3}{*}{ Timber } & E & 199 & 119 & 91 & 160 & 172 & 34 & 775 \\
\hline & I & 220 & 73 & 67 & 153 & 175 & 36 & 724 \\
\hline & $\mathrm{E}+\mathrm{I}$ & 419 & 192 & 158 & 313 & 347 & 70 & 1499 \\
\hline \multirow[t]{3}{*}{ Sum 10 functions } & $\mathbf{E}$ & 1293 & 768 & 596 & 1062 & 1087 & 226 & 5032 \\
\hline & I & 1431 & 416 & 424 & 926 & 982 & 266 & 4445 \\
\hline & $\mathbf{E}+\mathbf{I}$ & 2724 & 1184 & 1020 & 1988 & 2069 & 492 & 9477 \\
\hline
\end{tabular}

${ }^{1}$ The AFTD contains data on a wide range of products and services provided by trees; a range of 10 of the most important functions is given here. Data are presented on the number of species given in the database as used for a particular purpose based on whether they are indigenous (I) or exotic (E) in origin to a particular geographic region. The database contains more species indigenous to Africa than to other geographic regions, which is a factor determining the greater number of total references to the African continent.

2 The AFTD contains data on use across the globe; mentions of uses for a range of six important regions are given here. The regions of Africa, Oceania and South America were defined here according to en.wikipedia.org/wiki/List_of_sovereign_states_and_dependent_territories_by_continent. The regions of South Central Asia, South East Asia and Western Asia and Middle East were defined according to www.nationsonline.org/oneworld/asia.htm 
The importance of smallholder cultivation of exotic species is confirmed by an analysis of 120 tree species important to smallholders (data also compiled from entries in the AFTD). It revealed that each species had on average been planted in 21 countries outside its native range. Many of these introductions appear, however, to have been sub-optimal from a production perspective, with transfers frequently undocumented and haphazard. Surveys of distribution and use clearly demonstrate the past and future importance of cross-border transfer of tree germplasm to better meet smallholders' needs, a point emphatically made when the case of tree commodity crops is considered, as described below. At the same time, the dangers of new introductions, due to the weedy and potentially invasive characteristics of many trees, are also obvious; these have not always been sufficiently considered, and potential problems need to be guarded against (see thematic study on international exchange; also Ewel et al. 1999).

\section{The value of tree commodity crops for smallholders: exploring export trade data}

FAO's Statistics Division compiles information on the international trade of a number of commodity crops; data on global export values for a range of 12 tree commodities that are grown primarily in the tropics are given in Fig. 1, amounting to more than USD 66 billion based on figures for 2009. In that year, the five most important commodities listed in the figure are palm oil (from oil palm ${ }^{3}$, Elaeis guineensis), coffee (primarily from Coffea arabica), rubber (Hevea brasiliensis), cocoa (from cacao, Theobroma cacao) and tea (primarily from Camellia sinensis). The most notable feature of the graph is the rise in palm oil export value in the last two decades, to overtake green coffee exports. The actual value of other tree commodities shown in the graph will sometimes be considerably higher than reported here because much of the crop is sold in local markets rather than exported. Perishable fruits such as mangoes are a good case in point (Mohan Jain and Priyadarshan 2009). Nevertheless, export values provide an indication of the overall importance of a crop, with on average significant jumps in commodity prices evident in recent years.

\footnotetext{
${ }^{3}$ Palms - such as oil palm and the other palms referred to in this paper - are by definition not 'true' trees, but as perennial species derived from forests are classed as trees for the purposes of the current discussion.
} 


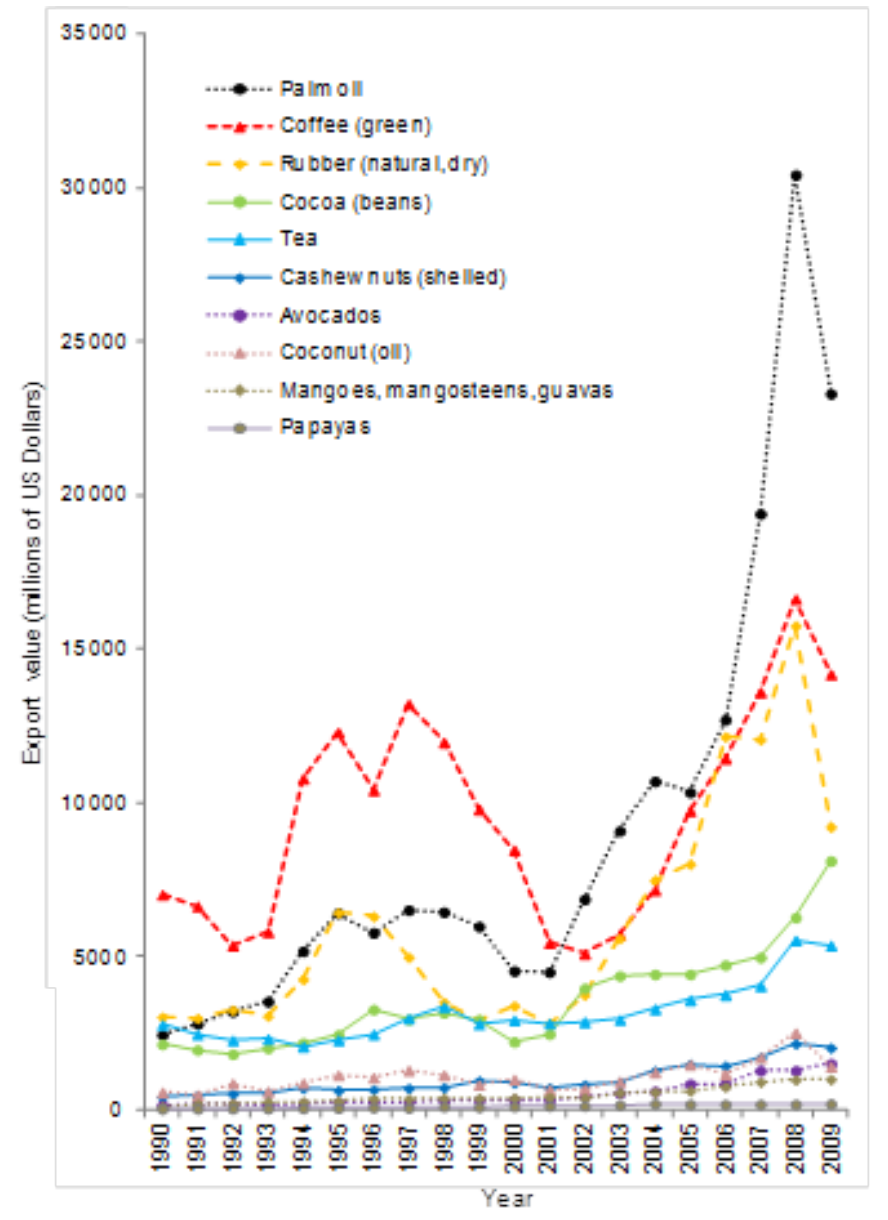

Data were extracted from the TradeSTAT database of FAOSTAT (faostat.fao.org/). Data for mangoes, mangosteens and guava are reported together. Values include re-exports (i.e., import into one nation followed by export to another). Some commodities, such as coffee, cocoa and coconut, are exported in more than one form; for each crop, only the most important form by export value is given here.

Figure 1: Global export values of a range of tree commodity crops for the years 1990 to 2009 (combined figures for all nations providing data).

In Indonesia, around $40 \%$ of palm oil production has been reported to come from smallholders (IPOC 2006), while approximately $30 \%$ of land planted to oil palm in Malaysia is reported to be under the management of small farmers (Basiron 2007). Many smallholders appear to have benefited substantially from oil palm planting, although required interventions include promoting transparency in the market and clearer land rights (Rist 2010). Moreover, greater than two-thirds of coffee production worldwide is on smallholdings (www.ico.org/). In East Africa, for example, it is estimated that approximately 700,000 smallholders grow coffee in Ethiopia, and 400,000 in Kenya (Place et al. 2012). Much of the coffee in eastern Africa is found in the highlands and plays a significant role as perennial land cover that helps to protect hillsides against soil erosion.

With natural rubber, there has been a trend toward increased smallholder production, partly because estates have switched to less labour-intensive crops such as oil palm (see INFO COMM at www.unctad.info/infocomm). Some estimates suggest that more than three-quarters of rubber production between 1998 and 2003 was on holdings of less than 40 ha (most on smallholdings of 2-3 ha), with an average annual increase in smallholder production of $3 \%$ over this period, compared to $1 \%$ for plantations, although large state-managed plantations still predominate in some former centrally planned economies. The use of higher yielding rubber clones rather than the collection of seedlings, and 
better management practices that reduce input costs and retain some biodiversity in rubber agroforests, have been successfully promoted with smallholders and have been shown to be more profitable than alternative practices in Indonesia (Wulan et al. 2006).

Similarly, more than $90 \%$ of cocoa production originates from smallholdings that typically cover 2-5 ha of land, although large plantations can be found in some countries (www.icco.org/). Worldwide, there are approximately 6 million cocoa farmers and it is estimated that around 14 million people depend directly on the cocoa crop, with many more indirectly, in West Africa alone. Rising prices mean there is more interest in making the best use of existing land by upgrading cocoa production methods. Current work through private-public partnerships between research institutions, NGOs, government and the chocolate industry in Indonesia, Cote d'Ivoire and elsewhere is improving the management methods of smallholders, delivering significantly higher yielding varieties to replace or rehabilitate (through grafting) old cacao trees, and improving market access through group sales (www.cocoasustainability.com/). A danger, however, is that higher prices may lead to a monoculture trend, with risky dependence on cocoa alone and hardship between production seasons (Edward Millard, Rainforest Alliance, www.rainforest-alliance.org, personal communication). In many countries, tea production is also mainly by smallholders; it has been reported that about $75 \%$ of tea in Sri Lanka is grown by small-scale farmers (who are defined as having holdings of less than 35 ha), whilst more than $50 \%$ is produced by small-scale growers in Kenya, although in some locations plantation production predominates (www.unctad.info/infocomm).

\section{Harvesting and cultivating tree foods to support nutrition}

Many people in low-income nations suffer from poor nutrition, with a lack of micronutrients, otherwise known as 'hidden hunger', leading to poor health consequences for hundreds of millions. In Africa, where the situation is worst, around 50 million children are, for example, at risk of vitamin A deficiency, the continent's third greatest public health problem after HIV/AIDS and malaria (Black et al. 2008). Solving malnutrition requires a range of interconnected approaches that include the bio-fortification of staple crops such as maize and rice, greater spending on food supplementation programmes, and the use of a wider range of edible plants for more diverse diets (UNICEF 2007, Negin et al. 2009). The further promotion of edible indigenous fruits, nuts and vegetables, including those provided by trees, is an attractive option, as it allows consumers to take responsibility for their diets in culturally relevant ways (Keatinge et al. 2010). Furthermore, the biochemical profiles of these indigenous species in supplying micronutrients, fat, fibre and protein are often better than staple crops (Leakey 1999). The nutritional value of many forest foods is however unknown, including what genetic variation in nutritional quality is present within species, and further testing and compilation of data are required (Colfer et al. 2006).

Communities in many parts of the tropics already incorporate many edible NWFPs harvested from forests into their diets as an important component, and a few depend on them; it has been reported that the role of these products is especially important for filling seasonal and other cyclical food gaps (Arnold et al. 2011). In addition, forests provide woodfuel needed to cook food to make it safe for consumption and palatable, and income from the sale of other products that can then be used to purchase food. Current nutritional deficiencies in several parts of the tropics are however exacerbated by deforestation for the agricultural production of a few staple foods, which means that local 
communities can no longer gain as easy access to natural stands of fruits, nuts and other edible NTFPs that they once collected to diversify their food intake.

Developing domestic markets for tree foods to address nutritional deficits and enhance livelihoods: the case of smallholder fruit production in sub-Saharan Africa

The recommended daily consumption of fruit and vegetables is a minimum of $400 \mathrm{~g}$ per person (World Health Organization [WHO] guidelines) but in sub-Saharan Africa it is significantly lower (Ruel et al. 2005,

faostat.fao.org/). Figures for fruit consumption in East Africa are illustrative, at a mean of around only $35 \mathrm{~g}$ per person per day, one of the lowest levels in the world. One reason why current consumption is so low is that households with limited incomes focus on purchasing staple crops that provide relatively cheap and 'concentrated' sources of carbohydrate to meet basic energy needs, leaving only a small fraction of the family budget to spend on other foods (Ruel et al. 2005).

Domestic markets for fruit are, however, predicted to grow rapidly in the next decades in sub-Saharan Africa (by about $5 \%$ per year over the next 10 years) as economies grow and provide local consumers with more income to spend on fruit, and as human populations increase and a trend to urbanization continues. Millions more tonnes of fruit need to be consumed to meet WHO guidelines, indicating the potential for improving farmers' incomes in supplying domestic markets in the order of billions of US Dollars, if production and delivery to consumers can be made more efficient.

One opportunity to influence child nutrition in the sub-continent involves 'home-grown school feeding' (HGSF). Traditionally, school feeding programmes in food-insecure areas have relied on foods of limited nutritional quality and variety that have often been sourced from outside (Bundy et al. 2009, WFP 2009). In contrast, HGSF initiatives seek to link schools with local agricultural producers to promote a more diverse, nutritionally-balanced range of foods. HGSF programmes are currently in the pilot stage, with the New Partnership for Africa's Development (NEPAD) and the World Food Programme inviting 12 countries to test implementation, and political support for HGSF is expected to grow in future years. Children can be effective agents of change in society, and teaching them about the value of fruit consumption can result in wider, positive attitudinal and behavioural changes in communities.

Another notable opportunity is to supply the rapidly developing supermarket sector in the sub-Saharan region, although these retailers may favour linkages with medium- or large-scale farmers rather than smallholders, as this provides them with greater control over the supply chain (Neven and Reardon 2004). Required innovation to make sure smallholders are included may involve the development of farmer producer groups that can negotiate with retailers and adhere to quality standards more effectively.

See Jamnadass et al. (2011) for further information.

In these circumstances, the cultivation of trees for foods once obtained from forests has the potential to improve health and incomes though local consumption and sale. Special potential for cultivation lies in the great biological diversity of indigenous foods found growing in forests that are important locally but have to date been under-researched by the scientific community. As well as supporting livelihoods, the cultivation of these species in farmland allows them to be conserved outside threatened forests, helping to maintain resources for future use and further development as food crops. 


\section{BIOLOGICAL VULNERABILITY TO CLIMATE CHANGE}

\section{Constraints to projecting climate change impacts on agroforestry systems}

Compared to simpler agricultural systems, very little research has been done on the impacts of climate change on agroforestry systems. This statement holds true for both experimental and model-based research. Spatial dimensions, time to reach maturity and the complexities of above- and below-ground interactions between often diverse assemblages of crop and tree species make experimental trials of agroforestry systems very difficult to implement and maintain in the field. While field crops can be grown relatively easily under controlled-climate conditions, this is much more difficult for trees Establishing fully mature agroforestry systems in growth chambers is near impossible. However, some experimental research is possible and has been conducted to investigate the possible consequences of climate change during the early stages of establishment of agroforestry systems. Provenance trials, in which tree specimens originating from different locations are grown in common gardens, can also be used to derive information on species' climate responses. For many exotic agroforestry species (e.g. Calliandra calothyrsus and Gliricidia sepium), such trials have been conducted. However, to our knowledge, these data have yet to be systematically evaluated with a view to climate change. For most tree species grown in agroforestry systems, virtually no information on climate responses is available. The same is true for tree responses to elevated $\mathrm{CO}_{2}$.

Due to scarcity of information on how trees and agroforestry systems respond to climate, there are no agroforestry models that can reliably be used for projecting the impacts of climate change. Ecological niche modelling offers an alternative, but caution should also be applied when interpreting results from this procedure. This method is typically applied to natural ecosystems, where the presence or absence of a species depends primarily on features of the natural environment. Agricultural crops are only present where farmers decide to plant them. This decision is determined at least as much by access to markets, profitability and cultural preferences as by the natural environment. For agroforestry systems in particular, distribution systems are determined to a large extent by tradition (for traditional systems), extension efforts (for innovative systems) or by the presence of processing and marketing infrastructure (for cash crop systems, such as coffee, cocoa etc.). Where these factors are absent, the respective system may not establish, even though climatic and environmental conditions are favourable. Where collected evidence on the presence of species (or in this case agricultural systems) does not cover the full range of suitable habitats, as is very likely in the case of agroforestry systems, ecological niche modelling is likely to exaggerate the impacts of climate change.

To obtain reliable projections of climate change impacts on agroforestry systems, process-based models of such systems should be developed. Due to the complexity of most of these systems, a great effort may be needed to achieve this. However, this effort is justified by the opportunity to expand the reach of agricultural systems models to hundreds of millions of smallholder farmers who produce food in systems that are too complex to be described by currently existing models.

\section{Work on system components}

Esmail and Oelbermann (2011) analyzed the response of seedlings of the agroforestry species Cedrela odorata and Gliricidia sepium under controlled temperature and $\mathrm{CO}_{2}$ conditions. They showed that elevated temperature accelerated seedling growth. At current temperature levels, raising $\mathrm{CO}_{2}$ 
concentrations to $800 \mathrm{ppm}$ had negative effects on the growth of both species. Increasing the temperature had positive effects. When $\mathrm{CO}_{2}$ concentrations and temperatures were increased, the response of $G$. sepium did not differ much from the elevated temperature treatment. In contrast, $C$. odorata growth was greatly increased in this treatment. Elevated carbon treatments greatly increased the shoot/root ratio and lowered leaf nitrogen concentrations. These results imply that for the species analyzed and for Costa Rican climate conditions (as replicated in a growth chamber in Canada), climate change will likely accelerate growth, but change plant nutrient levels in ways that are likely unfavourable for the productivity of agroforestry systems.

Schwendenmann et al. (2010) evaluated the response of a cacao/Gliricidia agroforestry system in Sulawesi (Indonesia) to a 13-month experimental drought. They found relatively small and mostly insignificant changes in cacao and Gliricidia sap flux densities, leaf litter fall, soil carbon efflux and cacao yield. Only cacao bean yield was substantially reduced by the artificial drought. Since this indicator has the greatest economic importance for producers, the authors' conclusion that this system is remarkably drought tolerant is only partly understandable.

Luedeling et al. (2011a) projected climate change effects on winter chill, an agroclimatic factor that affects agroforestry systems that include temperate fruit trees. Winter chill is needed for allowing temperate fruit trees to overcome winter dormancy. Several models are available for quantifying winter chill, with the so-called Dynamic Model, which measures winter chill in 'Chill Portions', likely the most accurate one for most growing regions. In this study, a weather generator was used to evaluate daily weather station records for over 4000 weather stations around the world. The resulting site parameters were then used in conjunction with 18 future climate scenarios and idealized daily temperature curves to produce 100 years of hourly weather data for each location and climate scenario. For each point location, the number of Chill Portions that is exceeded with $90 \%$ probability in a given climate scenario was then calculated. Results from all stations were then interpolated globally, including correction for altitudinal variation. Winter chill was projected to decline progressively throughout the late $20^{\text {th }}$ and $21^{\text {st }}$ centuries (Fig. 2), especially for warm growing regions, casting doubt on the potential of subtropical and tropical growing regions of such fruits to maintain production of currently grown tree species and cultivars. Particularly in the subtropical growing regions of the Mediterranean region, southern Australia, subtropical China and southern North America, many production sites may lose almost the entire winter chill that is currently available. Assuming that current understanding of the temperature response of temperate trees during the dormancy season is accurate (which is quite uncertain), many production regions will likely become unsuitable for many currently grown tree species and cultivars. As for most other physiological processes occurring in trees, models for winter chill are relatively crude (Luedeling and Brown, 2011) and their sensitivity to climate change varies considerably (Luedeling et al. 2009). Very limited understanding on how tree processes respond to climate throughout the year are a fundamental limitation to quantitative projection of climate change effects. 


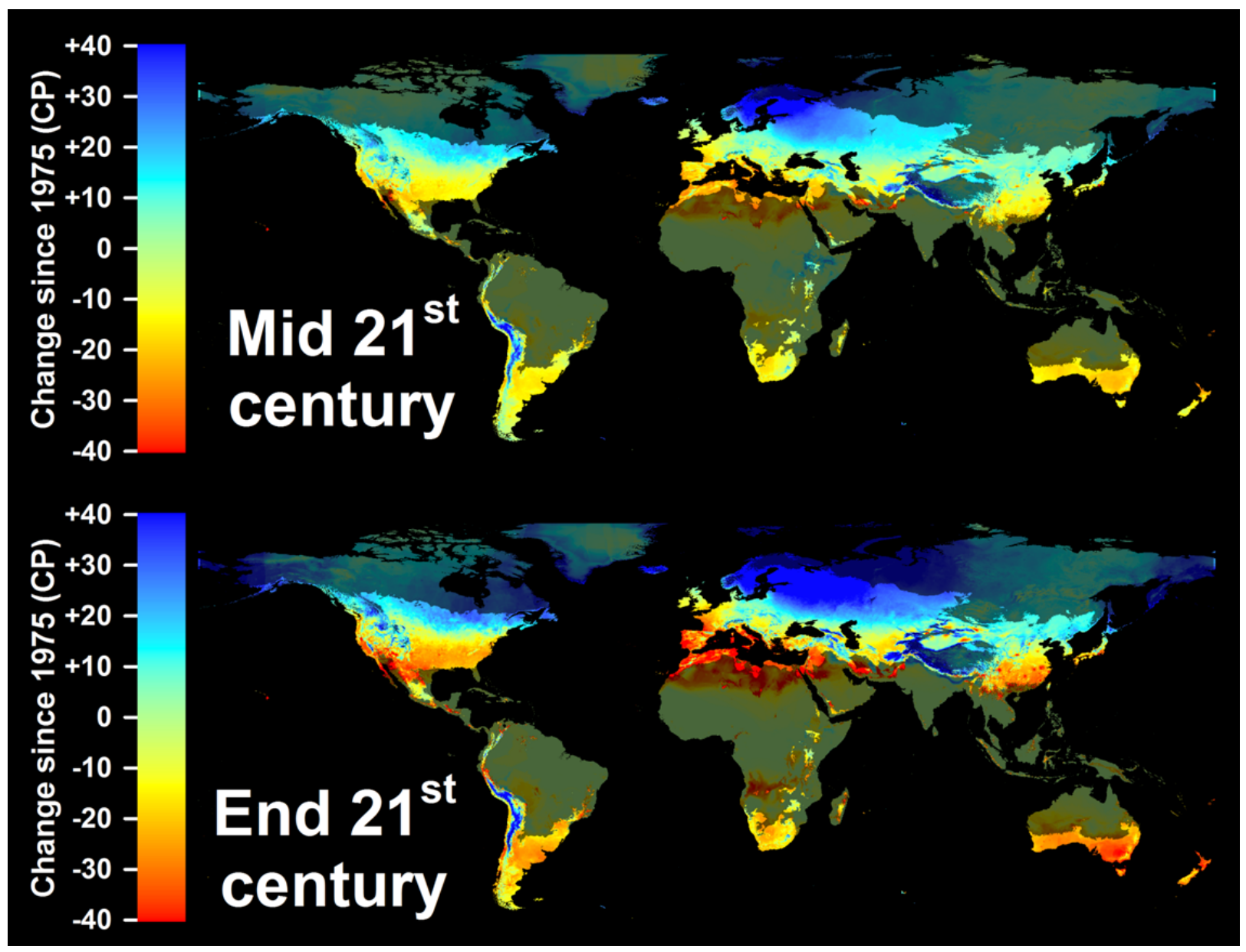

The two maps show averaged projections for three General Circulation Models, two greenhouse gas emissions scenarios for the 2050s (top map) and the 2080 s (bottom map). Safe Winter Chill is the amount of winter chill that is exceeded with $90 \%$ probability for a given scenario year. In the 1975 baseline (not shown), Safe Winter Chill estimates range from 0 CP in the Tropics to about 160 CP in maritime climates of Northern Europe (Luedeling et al. 2011a).

Figure 2: Projected losses in Safe Winter Chill (in Chill Portions - CP) around the world compared to a 1975 baseline scenario

In agroforestry systems, pollinators are instrumental in ensuring system functionality. Since many pollinators of crops and trees are ectothermic organisms, they will likely be affected by climate change, and if their rate of range shifts differs strongly from that of the plants that rely on them for pollination, ecosystem functions could be impaired. In a recent study focusing on historic shifts in North American plant and pollinator populations, Bartomeus et al. (2011) did not find evidence of such developments, but this may not be true for tropical contexts or for future climate changes. Yet Donnelly et al. (2011) list several cases of such mismatches in natural ecosystems. They suspect, however, that these are much more likely to affect very specialized plant-pollinator relationships. Where plants are primarily pollinated by generalist species, such as honey bees, system disruption seems much less likely. In an extensive review on recent pollinator decline, Potts et al. (2010) mentioned only few cases where pollinator loss was clearly attributable to climate change. These case studies mostly affected specialized pollinators, such as bumblebees and butterflies. There is a big data gap on climate change effects on pollination in tropical agroforestry systems, and research is urgently needed, in particular for systems that rely on specialized pollinators. 
Jaramillo et al. (2011) projected the likely impact of climate change on the Coffee Berry Borer (Hypothenemus hampei), a major pest of coffee agroforestry systems in East Africa. Using two future climate scenarios, they projected that pest pressure will increase substantially in Ethiopia, Uganda, Kenya, Burundi and Rwanda. In some growing regions, the number of possible generations of the Coffee Berry Borer was projected to double. This study mirrors results by Luedeling et al. (2011b), who projected strong increases in the number of generations that could potentially be completed by pests of walnut in California. These studies suffer from the constraint that the ecological interactions in complex ecosystems cannot be reliably modelled. They thus only provide worst-case estimates, assuming that pest insects will not be regulated by other biological processes, which may also be strengthened by climate change.

\section{Empirical approaches}

Besides process-based projections of climate change effects on components of agroforestry systems, we are not aware of process-based attempts to model tree-based cropping systems. Yet some impact projection studies have used species distribution modelling (also known as ecological niche modelling) to estimate future suitable ranges for systems. For parkland agroforestry systems in the West African Sahel, Luedeling and Neufeldt (revised version under review) used the Maximum Entropy approach to project future suitable ranges and potential carbon stocks, based on 101 locations obtained from published studies. These locations were used to characterize the ecological niche of parkland systems based on climatic parameters. The spatial extent of this niche was then projected for 18 future climate scenarios. Overlaying projections with a dataset on land use in the region produced estimates of the agricultural area that is suitable for parkland agroforestry. In all climate scenarios, suitability for parklands declined (Fig. 3). Using a MaxEnt suitability score of 0.2 as a cut-off threshold and the A2a and B2 SRES scenarios to represent a high and moderate climate change trajectory, suitable agricultural areas for parklands declined from 28 million hectares in the baseline scenario to between 22 and 27 million hectares by the 2020s, between 15 and 23 million hectares by the 2050s and between 2 and 18 million hectares by the 2080s. Evidently, climatic suitability is not the only factor that determines whether or not parkland systems will be established or maintained at a given location. It is quite conceivable that parklands could exist in many locations where they are currently not present. Yet it seems likely that farmers will maintain parkland agroforests in areas identified as climatically suitable in this study rather than in areas that were classified unsuitable. While the actual numbers given in the study are thus relatively crude and imprecise estimates, it is nevertheless expected that climatic suitability for parklands will decline over the $21^{\text {st }}$ century. 


\section{Agricultural areas suitable for parkland agroforestry}

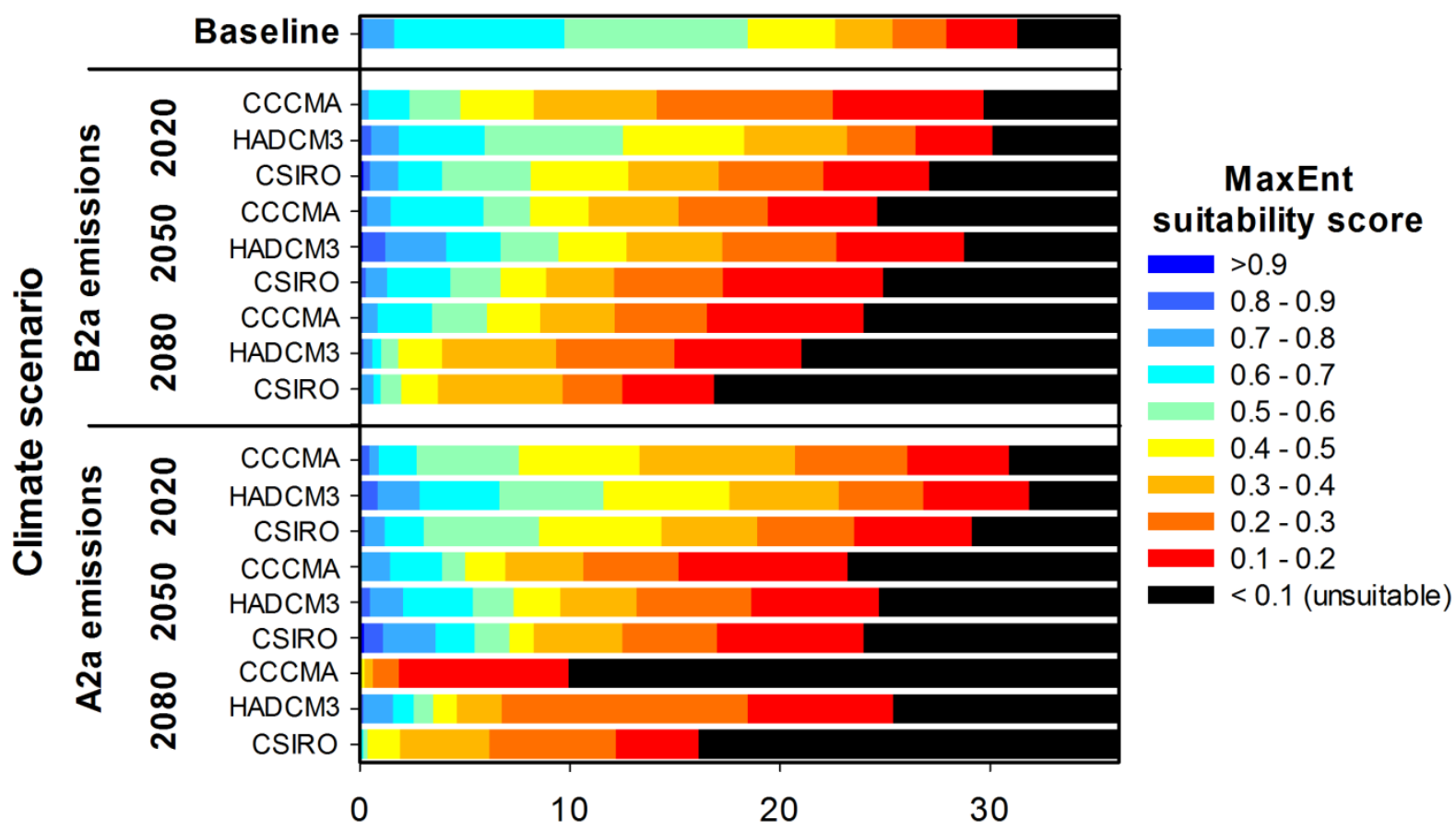

Agricultural area (million ha)

High MaxEnt scores signify high suitability. Scores of $\mathbf{0 . 2}$ or above were interpreted to imply suitability, rendering $\mathbf{7 7 \%}$ of Sahelian croplands suitable for parklands in the baseline scenario. For all future scenarios, suitable areas declined to between 5 and $74 \%$ of total cropland area.

Figure 3: Suitability of Sahelian cropland for parkland agroforestry, derived by ecological niche modelling with the Maximum Entropy (MaxEnt) method

These results contrast with modelling of future spatial distribution of grassland, savanna and deciduous and evergreen forest in West Africa with Generalized Additive Models (GAMs) using climate data from 17 General Circulation Models (GCMs) (Heubes et al. 2011). The results show strongest effects of climate change on grassland resulting in a northern expansion of its bioclimatic envelope in the magnitude of 2 million $\mathrm{km}^{2}$. However, uncertainty from different GCMs is generally high. Savanna is projected to lose area in the south $\left(54 \pm 22 \times 10^{4} \mathrm{~km}^{2}\right)$ while deciduous and evergreen forest are supposed to expand $\left(64 \pm 13 \times 10^{4} \mathrm{~km}^{2}\right.$ and $\left.77 \pm 26 \times 10^{4} \mathrm{~km}^{2}\right)$. The study indicates that at the scale analyzed, spatial distributions and transitions of biomes are governed by climate. The expected northward spread of grassland into the Sahara and the replacement of savanna by deciduous forest are concordant with results from Cramer et al. (2001) and Scheiter \& Higgins (2009), who attributed the greening to increased $\mathrm{CO}_{2}$ levels (higher water-use efficiency, fertilization effect). Heubes et al. 2011 indicate that climatic change alone can yield this pattern and assume that the biomes will follow shifting rainfall patterns caused by climate change. However, Luedeling (personal communication) casts doubt on the results that despite rising temperatures of approximately $2^{\circ} \mathrm{C}$ until 2050 and hence higher evapotranspiration, parts of the Sahara desert are expected to re-green. If only three climate variables (annual mean precipitation; minimum temperature of the coldest month; precipitation of the driest quarter) were used, higher expected rainfall may be balanced by higher evapotranspiration. Distribution of rainfall needs to be considered as well. This is only incompletely captured through the precipitation of the driest quarter of the year, which will likely continue to be zero in the drier parts of the study area. Temperature minima will probably not be critical for vegetation, but temperature maxima may well 
exceed the tolerable ranges of many species. The process used to select the variables for the biome modelling needs to be evaluated critically when it would have been possible to use the original 19 climate variables that reflect a much better picture of temperature extremes and rainfall distribution.

An indirect measure of the impacts of climate change on agroforestry systems can be derived by projected shifts in vegetation zones. The Vegetation and Climate Change in Eastern Africa (VECEA) project developed a high resolution map of potential natural vegetation for seven African countries (Ethiopia, Kenya, Malawi, Rwanda, Tanzania, Uganda and Zambia) and made this map available in atlas and online formats (Fig. 4; Lilles $\varnothing$ et al. 2011; van Breugel et al. 2011b). Various country-specific vegetation maps were harmonized through the development of a regional classification system of vegetation followed by an informed adjustment of vegetation boundaries (van Breugel et al. 2011a). Several of the national maps built on extensive ecological and botanical field surveys. Among the various potential application domains of the VECEA map, it can be readily used as a tree species selection tool since each vegetation type is accompanied by an extensive list of "useful tree species" (Kindt et al. 2011a; 2011b; 2011c; 2011d). Because reliable point-location data remain scarce for the majority of those tree species that can be integrated in forestry and agroforestry systems, the VECEA map is expected to provide a more reliable proxy of habitat suitability for a greater number of species than would be inferred by species distribution models. The VECEA map is also likely the best possible tree seed zonation map for the countries that it covers. By applying the precautionary principle that planting materials (such as seeds, seedlings or cuttings) of the same species should not be transferred across vegetation boundaries, failure of agroforestry or other tree planting projects due to a breakdown of genetic adaptation can be significantly reduced.

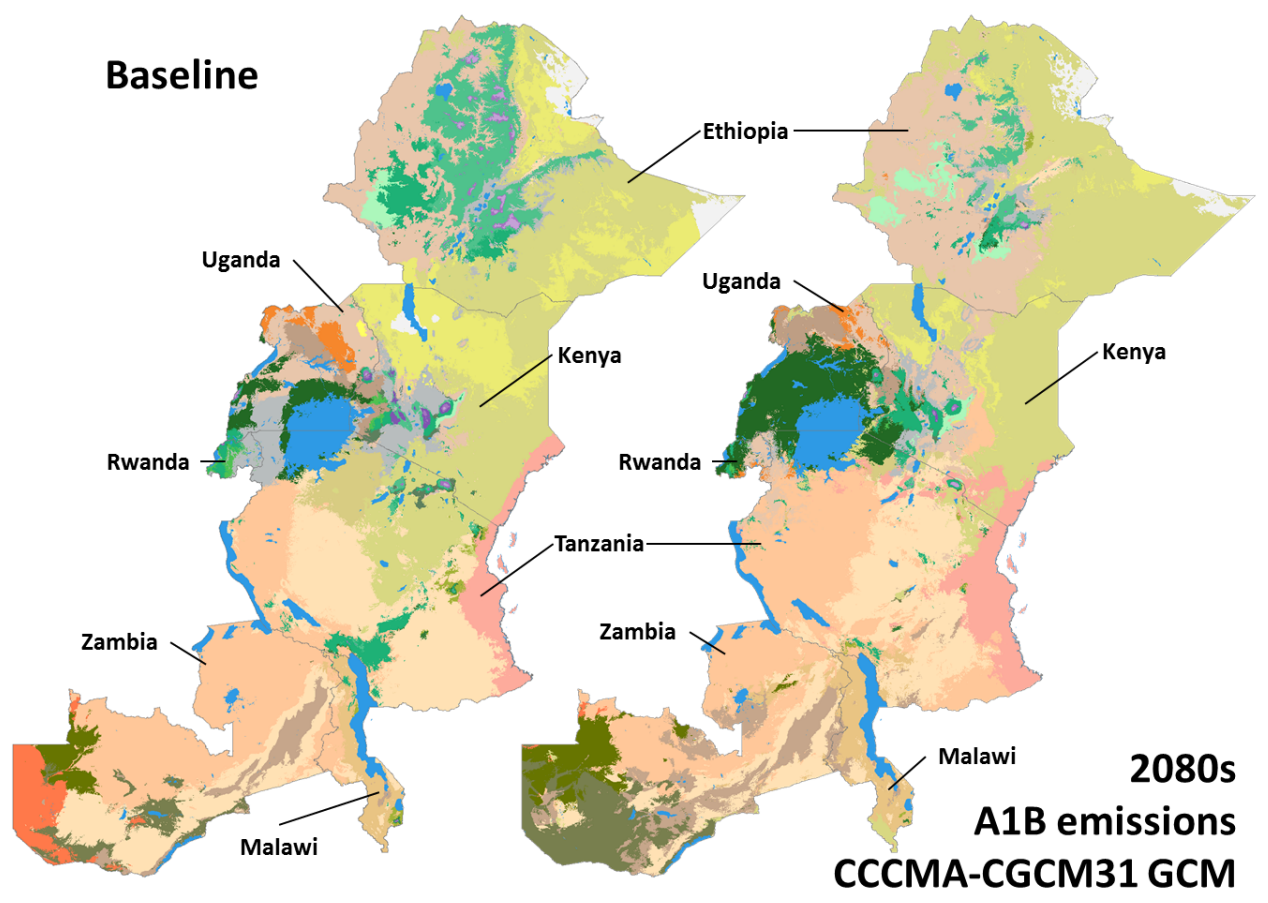

Left: modeled distribution of potential natural vegetation types in the VECEA map under long-term average conditions. Right: projected changes in the distribution of potential natural vegetation types under scenario A1B (model CCCMA-CGCM31). Full legends describing all vegetation types can be found in Lillesø et al. (2011).

Figure 4: Since each vegetation type (shown in different colours) is accompanied by an extensive list of "useful tree species", the VECEA map can be directly used as a spatially explicit selection tool for current and possible future climates 
Another application domain of the VECEA map is to project the possible effects of climate change. Each of the vegetation types that were known to be primarily under climatic control were subjected to suitability modelling through the maximum entropy algorithm; a consensus algorithm was subsequently used to assign the vegetation type with highest probability to each raster cell of the VECEA map (van Breugel et al. 2011b). With the exception of desert regions, this approach resulted in a very good approximation of the actual VECEA map. By extrapolating the modelling approach to possible future climates (available as statistically downscaled climate distribution layers), possible shifts in the locations of vegetation types were predicted (see Figure 4). Preliminary results showed that the choice of IPCC scenario or choice of General Circulation Model resulted in clear changes in the distribution of vegetation types. However, for many places the same vegetation type was predicted to occur for all scenarios or models. These results need to be interpreted with extreme caution since for many areas in the projected maps, probabilities of occurrence were low for all vegetation types, including the vegetation type chosen by our model as the most likely to occur (van Breugel et al. 2011b). These areas of low probabilities correspond to areas with climatic conditions that are currently rare or new. It should be noted that using species distribution modelling for climate change impact projections relies on a number of assumptions (Garcia et al. 2012). For example, biotic factors affecting ecosystems, such as pests and disease organisms, pollinators and microsymbionts, are assumed to migrate at rates corresponding to shift in vegetation types. It is also possible that new species assemblages will become established in novel climate regimes. Caution should thus be applied in interpreting the results from species distribution modelling studies.

\section{Uncovering past responses on trees to understand the impacts of climate change}

The techniques of tree-ring measurement and stable isotope analyses have been widely used to understand the long-term impacts of climate variations at the species, community and landscape levels, particularly in temperate regions. In tropical regions, however, the technique has only recently been introduced (Gebrekirstos et al. 2008; Gebrekirstos 2009). Gebrekirstos et al. (2008) studied long term climate growth relationships to assess differential drought impacts of co-occurring dry land species in Ethiopia. The results showed that during the period 1930-2006 about 17 severe and moderate droughts occurred during which all the studied species (Acacia senegal, Acacia seyal, Acacia tortilis and Balanites aegyptiaca) showed growth reductions of up to $90 \%$. Strong declines in tree-ring width correlated remarkably well with past EI Niño Southern Oscillation (ENSO) events and drought/famine periods in Ethiopia. Spectral analysis of the tree-ring chronology indicated occurrences of periodic drought events, which fall within the ENSO spectral peak equivalent to 2-8 years. Annual growth variations of all species were positively correlated with precipitation amount (Fig 5). However, the amount of decrease in the ring width index during drought and increase in moist years varied among the studied species. 


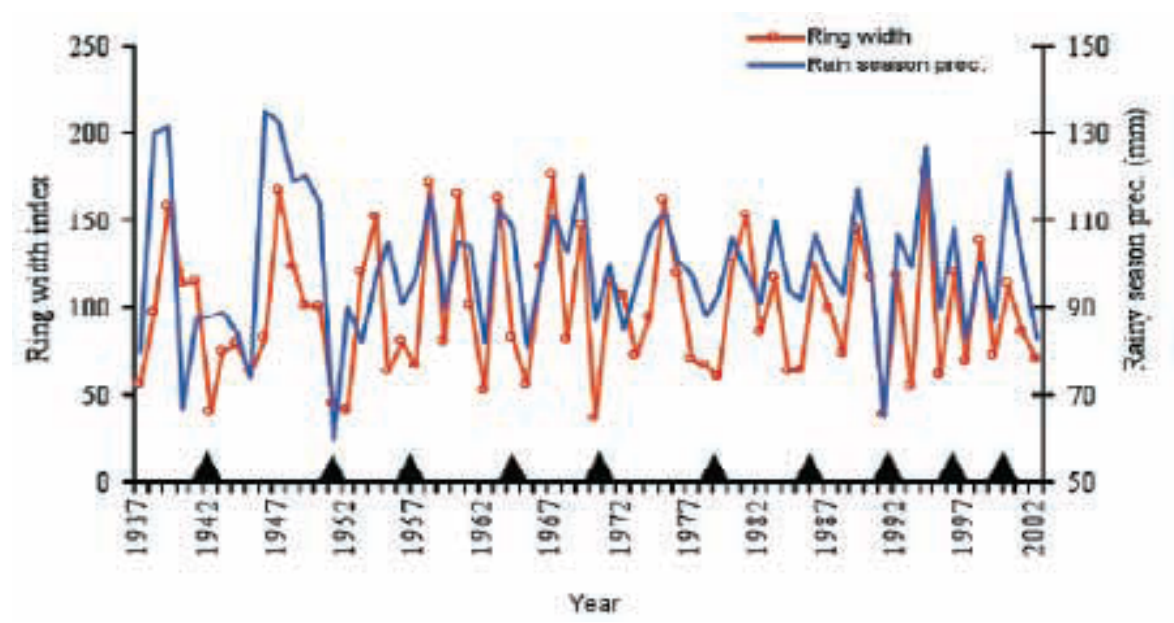

Figure 5: Master ring width indices and rainy season precipitation (June to September)

By using the growth information and stable carbon isotopes Gebrekirstos et al. (2011a) distinguished two contrasting water use strategies and competitive advantages. Species with lower mean $\mathrm{d} 13 \mathrm{C}$ values (A. senegal and $A$. seyal) showed better growth during moist years. Thus, they indicate low water use efficiency (WUE) and opportunistic water use strategy. On the other hand, $A$. tortilis and B. aegyptiaca showed relatively better growth performance and less increase in $\mathrm{d}_{13 \mathrm{C}}$ in drought years, reflecting their high WUE and conservative water use strategy. These results suggest that $\mathrm{d} 13 \mathrm{C}$ in tree rings can be useful in estimating historic changes in plant WUE and hence in screening drought tolerant species in the face of expected climate changes, as well as for assessing the functional diversity and risk reduction in mixed vegetation. This has implications on adaptation, for example, under drought prone conditions: species with a wide capacity to withstand hydrological changes may be an advantage while species with better growth performance could be suitable in areas of non-limiting water conditions. From similar studies in parkland agroforestry systems in West Africa, Gebrekirstos et al. (2011b) reported moisture and temperature to have significant effects on tree growth during the growing season, with the most important months being June to August. The strong climatic signal contained in stable oxygen isotope variations in tree rings will be useful to understand the hydrological cycle in the region.

Therefore, uncovering past responses to climate change could help in understanding the impacts of climate variability and the way society and ecosystems respond to them and it provides a huge potential to make informed climate projections.

\section{Using information from genetic trials and studies in natural populations in climate change adaptation planning}

In regions where there are strong geographical gradients in rainfall, one would expect significant genetic and phenotypic variation in tree growth, wood properties and other variables correlated with tree growth along the rainfall gradients. This information can be used to plan diversification of parklands for future climatic conditions. For example, if provenances from drier locations have better growth and survival when tested in dry sites and it is expected that the climate will become drier in the future, then it would be prudent to use seed from the drier locations for future plantings in the region. In this section, we present a few examples of results from provenance/progeny trials and studies in natural populations to show how they can be used in adaptation planning. 
Rural communities in the West African Sahelian and Sudanian ecozones value more than 90 native tree/shrub species for fuelwood, construction wood and other wood products. However, there are only two studies of genetic variation in tree growth and wood properties of native tree species related to the rainfall gradients in West African Sahelian-Sudanian ecozones, but they confirm that there is significant genetic variation related to rainfall, presumably reflecting the effects of natural selection over many generations. Provenances/progeny trials of Prosopis africana and Balanites aegyptiaca were established at one relatively dry site in Niger: seeds for the trials were collected in Niger (both species) and in Burkina Faso (P. africana only). Results indicate that provenances of both species originating from drier locations had significantly better above-ground growth compared to provenances originating from more humid locations (Weber et al. 2008; Weber and Sotelo Montes 2010). In addition, survival and wood density of P. africana was significantly greater for provenances originating from the drier locations (Weber et al. 2008; Sotelo Montes and Weber 2009). In contrast, calorific value of the wood, which expresses the energy content for use as fuel, was greater for provenances of both species originating in more humid locations (Sotelo Montes et al. 2011). Based on these results and considering projected climate change, researchers recommended that it would be prudent to (a) collect seed of these species (and other species) in drier locations for future planting in the region, and (b) multilocation provenance/progeny trials of other species should be established and used for adaptation planning in the region. These recommendations were adopted by an IFAD-funded development project that works with rural communities in Burkina Faso, Mali and Niger.

\section{SOCIOECONOMIC VULNERABILITY OF AGROFORESTRY TO CLIMATE CHANGE}

Agroforestry systems may range from very open parkland type assemblages of trees with livestock or dryland agriculture to dense imitations of tropical rainforests such as tree gardens. Determining socioeconomic vulnerability of agroforestry systems is therefore compounded by the diversity of the system as well as difficulty in distinguishing between climatic effects and other development related factors that may affect resource-poor farmers. In addition, there is a strong temporal variation of socioeconomic vulnerability because young agroforestry systems tend to produce little and may have higher costs than returns while mature agroforestry systems will generally produce positive externalities in terms of income, food security and ecosystem services.

This complexity is responsible for the small number of relevant studies that can clearly show how agroforestry systems contribute to managing climate risk. Trees on farms may mitigate direct climate impacts such as providing erosion control (Ma et al. 2009; Mutegi et al. 2008) or reducing the loss of grain production in drought years (Sileshi et al. 2011). But most of the effects are indirect in the sense that agroforestry tends to improve livelihoods and wellbeing and thereby reduces vulnerability to climate impacts as much as development related factors (Neupane and Thapa, 2001; Mithöfer and Waibel, 2003; Garrity et al. 2010). For example, smallholder farmers in western Kenya plant trees mainly as a living 'savings account' that allows them to pay for regular expenses (e.g. school fees) and emergencies. They prefer Grevillea robusta as a boundary tree over most other species because of its high growth rates, lack of competition with annual crops and the ability to prune it regularly for firewood (Neufeldt, unpublished data). Most of the case studies presented below given below are based on a comparison of normal years with drought or flood years since this is the best way to evaluate the direct and indirect effects of agroforestry vs. conventional agricultural systems. 


\section{Direct effects}

Soil erosion is a serious problem in cultivated areas of the central highlands of Kenya as there is strong negative correlated to maize production parameters. Mutegi et al. (2008) estimated how crop yields might be affected by introducing different erosion control measures into the conventional maize monocropping system. Their results showed that napier grass (Pennisetum purpureum) alone had the highest erosion mitigating effects but that this was accompanied by a loss in maize production. However, a combination of napier grass with leguminous shrubs (Leucena trichandra or Calliandra calothyrsus) led to a reduction of erosion and an enhancement of maize production and soil fertility, particularly in the second year of establishment of the hedges (Table 3). Identifying the multiple interacting effects is therefore necessary to evaluate the vulnerability to agroforestry systems to climate impacts. On the landscape scale Ma et al. (2009) showed that land-use change towards greater tree density reduced surface flows during the monsoon in south-west China, offsetting a trend towards greater rainfall. Although no economic data were collected in the study, it must be assumed that greater surface runoff will increase soil erosion and deplete soil fertility with detrimental effects on yields.

Table 3: Maize yield at Kirege farms in plots served by various vegetative hedges during the first and second season of the trial

\begin{tabular}{|c|c|c|c|}
\hline Treatment & $\begin{array}{l}\text { First season } \\
\text { Maize grain }\left(\mathrm{t} \mathrm{ha}^{-1} \pm 1 \mathrm{SE}\right)\end{array}$ & $\begin{array}{l}\text { Second season } \\
\text { Maize grain }\left(\mathrm{t} \mathrm{ha}^{-1} \pm 1 \mathrm{SE}\right)\end{array}$ & $\begin{array}{l}\text { Treatment mean } \\
\text { Maize grain }\left(\mathrm{t} \mathrm{ha} \mathrm{h}^{-1} \pm 1 \mathrm{SE}\right)\end{array}$ \\
\hline Control & $2.2 \mathrm{a} \pm 0.5(121)$ & $2.0 \mathrm{a} \pm 0.3(122)$ & $2.2 \mathrm{a}$ \\
\hline Calliandra & $1.9 \mathrm{a} \pm 0.4(124)$ & $3.2 \mathrm{~b} \pm 0.4(124)$ & $2.6 \mathrm{ab}$ \\
\hline Leucaena & $2.1 \mathrm{a} \pm 0.6(125)$ & $3.3 b \pm 0.5(116)$ & $2.7 \mathrm{~b}$ \\
\hline Napier & $0.9 \mathrm{~b} \pm 0.1(114)$ & $2.1 \mathrm{a} \pm 0.4(115)$ & $1.5 \mathrm{c}$ \\
\hline Calliandra + Napier & $2.2 \mathrm{a} \pm 0.7(119)$ & $3.4 \mathrm{~b} \pm 0.8(122)$ & $2.8 \mathrm{~b}$ \\
\hline Leucaena + Napier & $2.3 \mathrm{a} \pm 0.8(122)$ & $3.6 \mathrm{~b} \pm 0.6(116)$ & $2.9 \mathrm{~b}$ \\
\hline
\end{tabular}

Values are mean yield \pm SE; values in parentheses represent the number of observations $(n)$

For each column, means followed by different letters indicate significant difference based on Fisher's protected LSD test $(P=0.05)$

Sileshi et al. (2011) used rain-use efficiency ${ }^{4}$ (RUE) as an indicator to assess productivity of different management systems independent of the precipitation effect. Figures 6 and 7 show this relationship for sites in Zambia and Nigeria, respectively. The figures clearly show a general loss of productivity in two drought seasons for all management systems studied. But maize associated with leucena showed higher RUE and at least $50 \%$ higher yields than unfertilized maize. Though fully fertilized maize showed higher RUE than maize associated with leucena in Zambia, leucena intercropped with maize fared better than fully fertilized maize in the Nigeria case study. However, smallholder farmers in Zambia seldom use more than one third of the recommended amount of fertilizer suggesting that the high RUE estimated in the Zambia case may not be typical of field conditions. It should also be noted that in the Nigeria case study, leucena with maize fared worst of all management practices until the second year and only thereafter was effective in providing higher RUE and yields than all but the leucena and fertilizer treatment. This is a feature often observed in agroforestry systems where the benefits accrue later than

\footnotetext{
${ }^{4}$ Rain-use efficiency is defined as production divided by rainfall.
} 
in conventional systems. For resource-poor farmers with very high opportunity costs to land this may lead to decisions made against implementation of trees on farms (Thorlakson and Neufeldt, submitted).
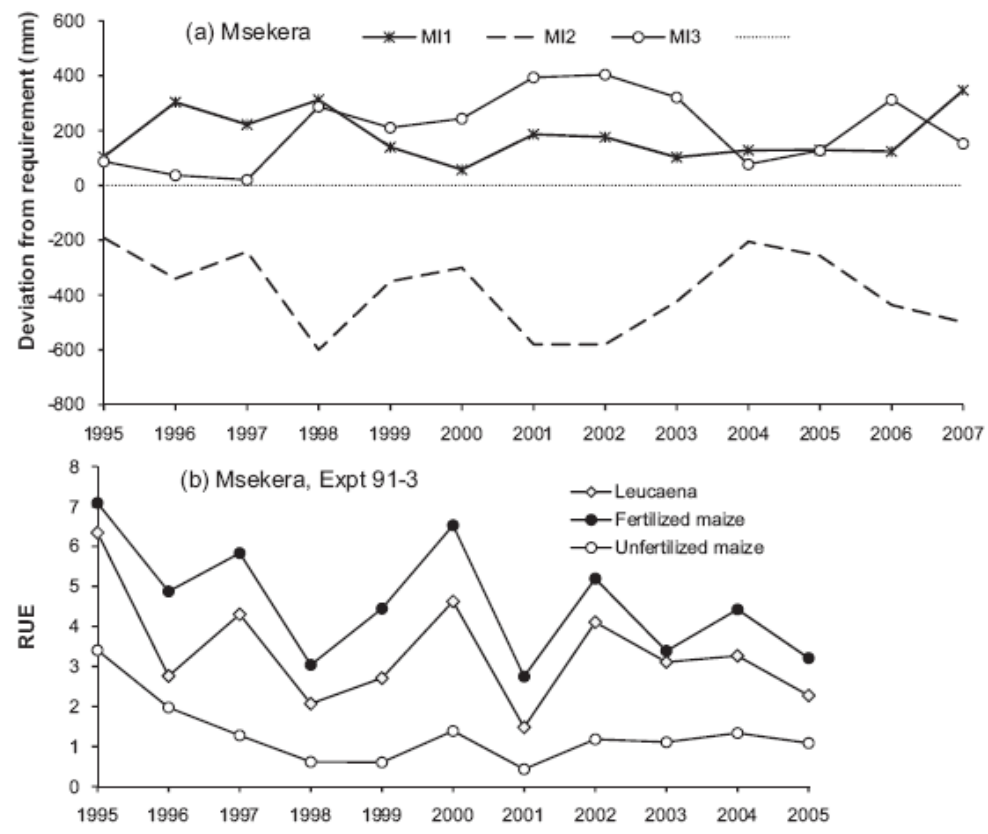

Maize production in rain deficit years (1998 and 2001-2002 (dashed line indicates rain deficits) was at least double the performance of unfertilized maize.

Figure 6: RUE in Msekera, Chipata, Zambia
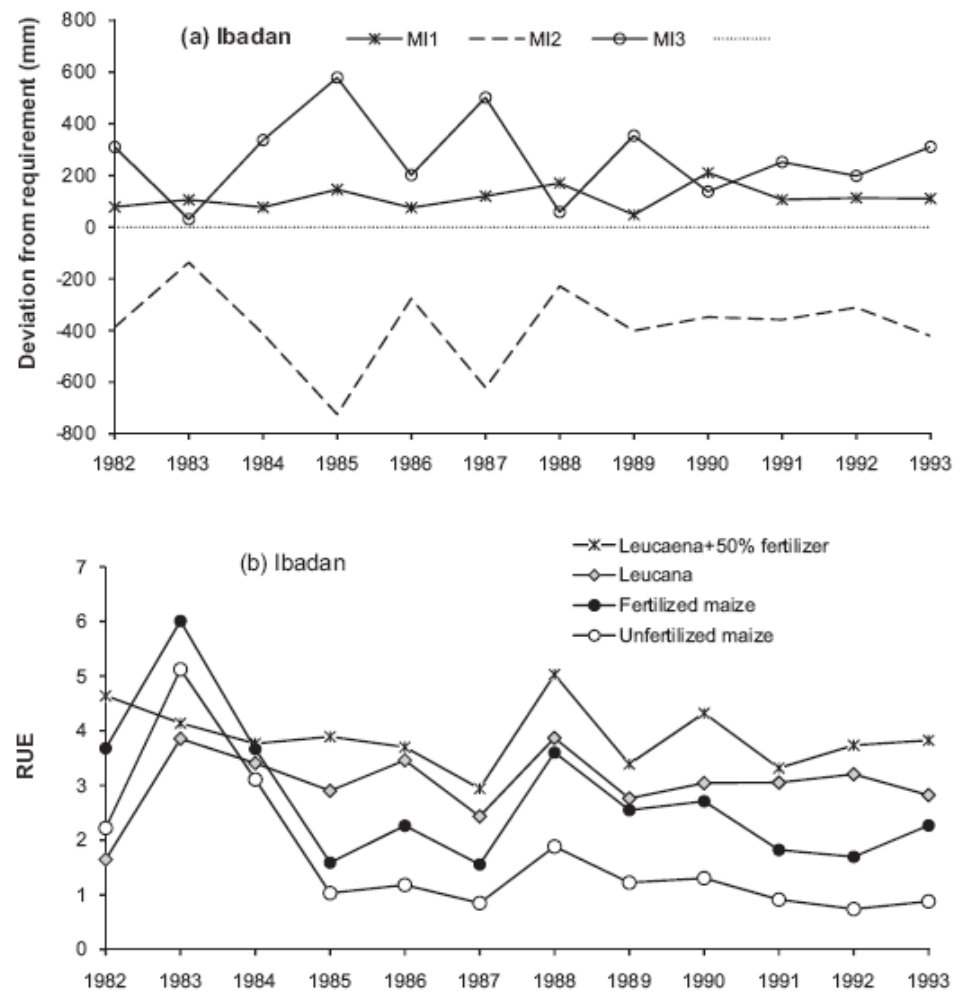

Note that in 1985, maize intercropped with leucena had yields at least $\mathbf{5 0 \%}$ greater than fertilized maize during the greatest moisture deficit.

Figure 7: RUE and yield stability in Ibadan, Nigeria 


\section{Indirect effects}

While the above mentioned mechanisms mitigate climate impacts in agroforestry systems directly, most effects of agroforestry are expected to be indirect in the sense that agroforestry increases farmers' food security, livelihoods and income and thereby reduces climate vulnerability and raises the adaptive capacities. There are few quantitative results so far and few provide specific evidence on reduced climate vulnerability beyond a general increase in improved livelihoods and income. Nonetheless, for resource-poor farmers, being able to manage their daily challenges better with agroforestry is a clear indicator of reduced climate risk.

A study by Ajayi et al. (2005) evaluated the financial impact of agroforestry fallows in farmers' fields near Chipata, Zambia (Figure 4). Agroforestry in Zambia gives double the profit on investment that continuous maize gives, though not as much as full fertilization. Smallholders, however, rarely apply even one-quarter of the recommended rate of fertilizer. Greater cash flow provides greater security in the face of climate change than typical subsistence production.

Table 4: Profitability of maize production $\mathrm{ha}^{-1}$ using fertilizer tree fallows and subsidized fertilizer options over a 5-year cycle in Zambia

\begin{tabular}{l|l|c|c} 
Production sub-system & $\begin{array}{l}\text { Description of land-use } \\
\text { system }\end{array}$ & $\begin{array}{c}\text { Net present } \\
\text { value }\end{array}$ & $\begin{array}{c}\text { Cost- benefit } \\
\text { ratio }\end{array}$ \\
\hline Continuous, no fertilizer & Continuous maize for 5 years & 130 & 2.01 \\
\hline $\begin{array}{l}\text { Continuous fertilizer (subsidized at } \\
50 \% \text { ) }\end{array}$ & Continuous maize for 5 years & 499 & 2.65 \\
\hline $\begin{array}{l}\text { Continuous fertilizer } \\
\text { (at non-subsidized market price) }\end{array}$ & Continuous maize for 5 years & 349 & 1.77 \\
\hline Gliricidia sepium & $\begin{array}{l}\text { 2 years of Gliricidia fallow } \\
\text { followed by 3 years of crop }\end{array}$ & 269 & 2.91 \\
\hline $\begin{array}{l}\text { Sesbania sesban } \\
\text { 2 years of Sesbania fallow } \\
\text { followed by 3 years of crop }\end{array}$ & 309 & 3.13 \\
\hline Tephrosia vogelli & $\begin{array}{l}\text { 2 years of Tephrosia fallow } \\
\text { followed by 3 years of crop }\end{array}$ & 233 & 2.77
\end{tabular}

Note: Figures based on 1 ha, using prevailing costs and prices and an annual discount rate of $30 \%$.

Source: Ajayi et al. (2004)

From 2008 to 2011, ICRAF's Southern Africa region implemented the Agroforestry Food Security Program (AFSP) in 11 districts in Malawi. In 2010 a study was done by ICRAF with 360 farm families in 12 extension areas across six districts to estimate the effect of the agroforestry technologies on maize production. In 2011, a study was carried out by an independent assessment team with 483 farm families in six extension areas of five districts to evaluate the contribution of AFSP to food security for the major donor, Irish Aid. Farmer-reported maize yields with agroforestry were greater than those without agroforestry in all districts of the study, and were significantly greater across all districts (Table 5). Significant differences between the first two treatments and the third and fourth treatments may be due to increased micronutrients recycling in the cropping system with agroforestry compared with the urea fertilizer most commonly used on maize. The near-doubling of yields gives the farm family more choices among responses to increased variability of climatic conditions (Mwalwanda et al. 2012). Farmers mentioned eating more often (30\%); building up family food reserve (22\%); selling food (25\%); 
and exchange for farm inputs (13\%) as most common uses of the extra yields. The family food reserve, cash and farm input categories all represent reserves of value that that gives the family more flexible responses to increased variability of climatic conditions. Farmers participating in AFSP also reported slightly greater food security than non-participants, though the difference was not statistically significant, and greater dietary diversity and higher-quality foods (CIE 2011). Families that consume a greater variety of foods are better nourished and thus better able to tolerate food deficits, as well as having greater flexibility of food choices in years in which cereal yields are low.

\section{Table 5: Comparison of means of total maize vield at harvest $\left(\mathrm{kg} \mathrm{ha}^{-1}\right)$}

\begin{tabular}{llll} 
Plot management & Frequency & Mean & Standard error \\
\hline Maize without fertilizer & 36 & 1322 & 220.3 \\
Maize with fertilizer & 213 & 1736 & 119.0 \\
Maize with fertilizer trees & 72 & 3053 & 359.8 \\
Maize with fertilizer trees and fertilizer & 135 & 3071 & 264.3 \\
\hline
\end{tabular}

Thorlakson and Neufeldt (submitted) analyzed coping strategies in western Kenya during a drought in 2009 and flooding in 2010. Results showed that farm productivity dropped by $60 \%$ and $39 \%$ in the Lower and Middle Nyando catchment areas, respectively, which led to on average at least one month of food shortage in addition to the 4.5 and 2.3 hunger months experienced in normal years. During the hunger periods coping strategies consist of restriction in amount, diversity and number of meals taken each day. Selling of livestock at between $75 \%$ and $50 \%$ of market prices was also a typical measure. Farmers were also forced to use coping strategies that had detrimental effects in the long term such as selling oxen, which would not be available for ploughing; consuming seeds reserved for planting; leasing land; and engaging in casual labour. Farmers practising agroforestry typically used fewer of these detrimental coping strategies during hunger periods. Farmers with mature trees were able to sell seedlings, timber and firewood and consume fruit from their trees (Table 6). Farmers explained that the most effective way to reduce their vulnerability to the climate-related hazards was to diversify income, including off-farm income activities. Higher farm productivity also contributed to reducing the overall climate risk.

Table 6: Proportion of farmers using coping strategies to deal with flood and drought in 2009-2010

\begin{tabular}{|c|c|c|c|c|}
\hline & \multicolumn{2}{|c|}{ Lower Nyando } & \multicolumn{2}{|c|}{ Middle Nyando } \\
\hline & $\begin{array}{c}\text { Treated } \\
(\%)\end{array}$ & $\begin{array}{c}\text { Control } \\
(\%)\end{array}$ & $\begin{array}{c}\text { Treated } \\
(\%)\end{array}$ & $\begin{array}{c}\text { Contro } \\
(\%)\end{array}$ \\
\hline Reduce quantity, quality or \# of meals & 82 & 66 & 54 & 86 \\
\hline Help from gov, NGO, church & 40 & 47 & 11 & 25 \\
\hline Borrow money & 31 & 40 & 29 & 46 \\
\hline Casual labor & 24 & 40 & 32 & 18 \\
\hline Sell possessions or livestock & 73 & 66 & 36 & 43 \\
\hline Consume seeds & 67 & 80 & 50 & 71 \\
\hline Consume or sell fruit from trees & 40 & 25 & 68 & 38 \\
\hline$N=$ & 45 & 15 & 28 & 28 \\
\hline
\end{tabular}


Thorlakson and Neufeldt (submitted) also showed that ensuring food security ${ }^{5}$ appeared to be necessary before farmers were willing or able to invest in longer-term processes for improving other components of their wellbeing. This was evident when comparing the more food secure Middle Nyando with the less food secure Lower Nyando areas. Lower Nyando farmers rarely focused on goals not directly related to improving household food supply whereas Middle Nyando farmers frequently discussed goals related to expanding land holdings, improving children's education and investing in long-term projects to ensure financial security.

These results are complemented by Kristjanson et al. (accepted) who showed that proxies for food security were strongly correlated with farmers' 'innovativeness'. The baseline survey was carried out in five $10 \times 10 \mathrm{~km}^{2}$ sites in Ethiopia, Kenya, Uganda (2) and Tanzania and included responses of 700 farmers across a range of agricultural systems and environments. This study contributes to the evidence base of what smallholders are doing to adapt to changing circumstances, including a changing climate. They found that many households are already adapting to changing circumstances, and their changes tend to be marginal rather than transformational in nature, with relatively little uptake of existing improved soil, water and land management practices. The study was not able to identify the direction of the relationship, i.e. whether farmers who were more innovative were more food secure or whether food insecure farmers were not able to invest in more innovations. Most likely both interpretations are correct to some extent. The first interpretation would suggest that looking at the innovations of food secure farmers might help to scale up promising technologies. The second interpretation might imply that assisting food insecure farmers to invest in innovations, such as planting trees on farms may not be very effective.

Simelton et al. (2012) and Nguyen et al. (under review) identified similar effects of weather extremes on long-term food security in northern and central Viet Nam. Next to harvest loss that hit the farmers immediately, indirect effects such as damages on irrigation infrastructure or loss of seeds for planting can be very significant. In addition there are impacts of a changing climate on the farming system that may require adjusting the farming calendar and could affect subsequent crops. In response to climate shocks poorer farmers in central Viet Nam exploit forests for income whereas better-off farmers invest in strategies that manage risk, e.g. fertilizer and soil management, animal husbandry and investment in multipurpose trees on farms.

In order to overcome some of their vulnerabilities, poor farmers often rely on social safeguard systems (as opposed to financial safeguards). Chaudhury et al. (2011) described how social protection improves farmers' adaptive capacity and risk management in agroforestry contexts. Through case studies from Zambia and Honduras the paper demonstrated that linkages between social protection and adaptive capacity reinforce each other such that natural resource management through agroforestry leads to improved social protection and boosts adaptive capacity.

\footnotetext{
${ }^{5}$ Farmers defined food security as the ability to obtain an adequate diet for all household members throughout the year without being forced to use long-term savings to purchase food.
} 


\section{REFERENCES}

Ajayi OC, Agumya A, Kwesigia F. (2005) Agroforestry technologies for improved soil fertility and food security for resource-poor households in Africa: their geographic niches, adoption, and profitability. Working Paper 4, Chipata, World Agroforestry Centre, 29pp.

Arnold M, Powell B, Shanley P, Sunderland TCH. (2011) Editorial: forests, biodiversity and food security. International Forestry Review, 13, 259-264.

Bartomeus I, Ascher JS, Wagner D, Danforth, BN, Colla S, Kornbluth S, Winfree R. ( 2011) Climateassociated phenological advances in bee pollinators and bee-pollinated plants. Proceedings of the National Academy of Sciences of the United States of America, 108(51): 20645-20649.

Basiron Y. (2007) Palm oil production through sustainable plantations. European Journal of Lipid Science and Technology, 109, 289-295.

Black RE, Allen LH, Bhutta ZA, Caulfield LE, de Onis M, Ezzati M, Mathers C, Rivera J. (2008) Maternal and child under-nutrition: global and regional exposures and health consequences. The Lancet, 371, 243-260.

Bundy D, Burbano C, Grosh ME, Gelli A, Juke M, Drake L. (2009) Rethinking school feeding: social safety nets, child development, and the education sector. The World Bank, Washington DC, USA.

Chaudhury M, Ajayi OC, Hellin J, Neufeldt H. (2011) Climate change adaptation and social protection in agroforestry systems: enhancing adaptive capacity and minimizing risk of drought in Zambia and Honduras. ICRAF Working Paper 137, Nairobi.

CIE. (2011) Evaluation of ICRAF's Agroforestry Food Security Program AFSP 2007-2011. Centre for Independent Evaluations, Lilongwe, Malawi.

Colfer CJP, Sheil D, Kishi M. (2006) Forests and human health: assessing the evidence. CIFOR Occasional Paper No. 45. Center for International Forestry Research, Bogor, Indonesia.

Cramer W, Bondeau A, Woodward FI, Prentice IC, Betts RA, Brovkin V, Cox PM, Fisher V, Foley JA, Friend $A D$, Kucharik C, Lomas MR, Ramankutty N, Sitch S, Smith B, White A, Young-Molling C. (2001) Global response of terrestrial ecosystem structure and function to $\mathrm{CO}_{2}$ and climate change: results from six dynamic global vegetation models. Global Change Biology, 7, 357-373.

Donnelly A, Caffarra A, O'Neill BF. (2011) A review of climate-driven mismatches between interdependent phenophases in terrestrial and aquatic ecosystems. International Journal of Biometeorology, 55(6): 805-817.

Esmail S, Oelbermann M. (2011) The impact of climate change on the growth of tropical agroforestry tree seedlings. Agroforestry Systems, 83(2): 235-244.

Ewel JJ, O'Dowd DJ, Bergelson J, Daehler CC, D'Antonio CM, Gómez LD, Gordon DR, Hobbs RJ, Holt A, Hopper KR, Hughes CE, LaHart M, Leakey RRB, Lee WG, Loope LL, Lorence DH, Louda SM, Lugo AE, McEvoy PB, Richardson DM, Vitousek PM. (1999) Deliberate introductions of species: research needs. BioScience, 49, 619-630.

Garcia RA, Burgess ND, Cabeza M, Rahbeck C, Araujo MB. (2012) Exploring consensus in $21^{\text {st }}$ century projections of climatically suitable areas for African vertebrates. Global Change Biology, in press.

Garrity DP, Akinnifesi FK, Ajayi OC, Weldesemayat SG, Mowo JG, Kalinganire A, Larwanou M, Bayala J. (2010) Evergreen Agriculture: a robust approach to sustainable food security in Africa. Food Security 2: 197-214.

Gebrekirstos A, Bräuning A, van Noordwijk M, Mitlöhner R. (2011b) Understanding past, present, and future climate changes from East to West Africa. (Keynote paper) Agricultural Innovations for Sustainable Development 3(2): 77-86.

Gebrekirstos A, Mitlöhner R, Teketay D, Worbes M. (2008) Climate-growth relationships of the dominant tree species from semi-arid savanna woodland in Ethiopia. Trees - Structure and Function 22: 631-641.

Gebrekirstos A, Van Noordwijk M, Neufeldt H, Mitlöhner R. (2011a) Relationships of stable carbon isotopes, plant water potential and growth: an approach to asses water use efficiency and 
growth strategies of dry land agroforestry species. Trees - Structure and Function 25: 95-102, doi:10.1007/s00468-010-0467-0.

Gebrekirstos A. (2009) Climate change in Africa based on tree rings and stable isotope results, and its potential for climatic tele-connections. Agricultural Innovations for Sustainable Development 1 (2), 66-72.

Heubes J, Kühn I, König K, Wittig R, Zizka G, Hahn K. (2011) Modelling biome shifts and tree cover change for 2050 in West Africa. Journal of Biogeography, 38: 2248-2258.

IPOC. (2006) Statistik Kelapa Sawit Indonesia 2005. Indonesian Palm Oil Commission, Department of Agriculture, Jakarta, Indonesia.

Jamnadass RH, Dawson IK, Franzel S, Leakey RRB, Mithöfer D, Akinnifesi FK, Tchoundjeu Z. (2011) Improving livelihoods and nutrition in sub-Saharan Africa through the promotion of indigenous and exotic fruit production in smallholders' agroforestry systems: a review. International Forest Review, 13, 338-354.

Jaramillo J, Muchugu E, Vega FE, Davis A, Borgemeister C. (2011) Some like it hot: The influence and implications of climate change on coffee berry borer (Hypothenemus hampei) and coffee production in East Africa. PLoS ONE, 6(9).

Keatinge JDH, Waliyar F, Jamnadass RH, Moustafa A, Andrade M, Drechsel P, Hughes JA, Kadirvel P, Luther K. (2010) Relearning old lessons for the future of food - by bread alone no longer: diversifying diets with fruit and vegetables. Crop Science, 50, S51-S62.

Kindt R et al. (2011a) Potential Natural Vegetation of Eastern Africa (Ethiopia, Kenya, Malawi, Rwanda, Tanzania, Uganda and Zambia). Volume 5: Description and Tree Species Composition for Other Potential Natural Vegetation Types (Vegetation Types other than Forests, Woodlands, Wooded Grasslands, Bushlands and Thickets). Forest \& Landscape, University of Copenhagen. (Working Paper 65).

Kindt R et al. (2011b) Potential Natural Vegetation of Eastern Africa (Ethiopia, Kenya, Malawi, Rwanda, Tanzania, Uganda and Zambia). Volume 2: Description and Tree Species Composition for Forest Potential Natural Vegetation types. Forest \& Landscape, University of Copenhagen (Working Paper 62).

Kindt R et al. (2011c) Potential Natural Vegetation of Eastern Africa (Ethiopia, Kenya, Malawi, Rwanda, Tanzania, Uganda and Zambia). Volume 3: Description and Tree Species Composition for Woodland and Wooded Grassland Potential Natural Vegetation Types. Forest \& Landscape, University of Copenhagen (Working Paper 63).

Kindt R et al. (2011d) Potential Natural Vegetation of Eastern Africa (Ethiopia, Kenya, Malawi, Rwanda, Tanzania, Uganda and Zambia). Volume 4: Description and Tree Species Composition for Bushland and Thicket Potential Natural Vegetation Types. Forest \& Landscape, University of Copenhagen (Working Paper 64).

Kristjanson P, Neufeldt H, Gassner A, Mango J, Kyazze F, Desta S, Sayula G, Thiede B, Förch W, Thornton PK, accepted. Are food insecure smallholder households making changes in their farming practices? Evidence from East Africa. Food Security.

Leakey RRB. (1999) Potential for novel food products from agroforestry trees. Food Chemistry, 64, 1-14. Lilles $\varnothing$ JB et al. (2011) Potential Natural Vegetation of Eastern Africa (Ethiopia, Kenya, Malawi, Rwanda, Tanzania, Uganda and Zambia). Volume 1: The Atlas Forest \& Landscape. Forest \& Landscape, University of Copenhagen (Working Paper 61).

Luedeling E et al. (2011b) Climate change effects on walnut pests in California. Global Change Biology, 17(1): 228-238.

Luedeling E, Brown PH. (2011) A global analysis of the comparability of winter chill models for fruit and nut trees. International Journal of Biometeorology, 55(3): 411-421.

Luedeling E, Girvetz EH, Semenov MA, Brown PH. (2011a) Climate change affects winter chill for temperate fruit and nut trees. PLoS ONE, 6(5).

Luedeling E, Neufeldt $H$., revised version under review. Carbon sequestration potential of parkland agroforestry in the Sahel. Climatic Change. 
Luedeling E, Zhang M, Luedeling V, Girvetz EH. (2009) Sensitivity of winter chill models for fruit and nut trees to climatic changes expected in California's Central Valley. Agriculture, Ecosystems and Environment, 133(1-2): 23-31.

Ma X, Xu JC, Luo Y, Aggrawal SP, Li JT. (2009) Response of hydrological processes to land-cover and climate changes in Kejie watershed, south-west China. Hydrological Processes 23, 1179-1191.

Mithöfer D, Waibel H. (2003) Income and labour productivity of collection and use of indigenous fruit tree products in Zimbabwe. Agroforestry Systems 59, 295-305.

Mohan Jain S, Priyadarshan PM eds. (2009) Breeding plantation tree crops. Tropical species. Springer Science+Business Media, New York, USA.

Mutegi JK, Mugendi DN, Verchot LV, Kung'u JB. (2008) Combining napier grass with leguminous shrubs in contour hedgerows controls soil erosion without competing with crops. Agroforestry Systems 74, 37-49.

Mwalwanda AB, Ajayi OC, Akinnifesi FK, Beedy T, Sileshi G, Chiundu G. (2012) Impact of fertilizer trees on maize production and food security in six districts of Malawi. ICRAF Working Paper No 140. Nairobi (forthcoming).

Negin J, Remans R, Karuti S, Fanzo JC. (2009) Integrating a broader notion of food security and gender empowerment into the African Green Revolution. Food Security, 3, 351-360.

Neupane RP, Thapa GB. (2001) Impact of agroforestry intervention on soil fertility and farm income under the subsistence farming system of the Middle Hills, Nepal. Agriculture, Ecosystems and Environment 84, 157-167.

Nguyen HQ, Hoang MH, Öborn I, van Noordwijk M. (under review) Multipurpose agroforestry as a climate change adaptation option for farmers - an example of local adaptation in Viet Nam. Climatic Change.

Place F, Ajayi OC, Masters E. (2011) Tree-based and other land management technologies for landscape restoration and livelihood in Africa. In: Dewees P, Place F, Scherr SJ, Buss C (principal authors). Investing in trees and landscape restoration in Africa: what, where, and how. Program on Forests (PROFOR), Washington DC, USA.

Potts, SG et al. (2010) Global pollinator declines: trends, impacts and drivers. Trends in Ecology \& Evolution, 25(6): 345-353.

Rist L, Feintrenie L, Levang P. (2010) The livelihood impacts of oil palm: smallholders in Indonesia. Biodiversity and Conservation, 19, 1009-1024

Ruel MT, Minot N, Smith L. (2005) Patterns and determinants of fruit and vegetable consumption in sub-Saharan Africa: a multi-country comparison. International Food Policy Research Institute, Washington DC, USA.

Scheiter S. Higgins SI. (2009) Impacts of climate change on the vegetation of Africa: an adaptive dynamic vegetation modelling approach. Global Change Biology, 15, 2224-2246.

Schwendenmann L. et al. (2010) Effects of an experimental drought on the functioning of a cacao agroforestry system, Sulawesi, Indonesia. Global Change Biology, 16(5): 1515-1530.

Sileshi GW, Akinnifesi FK, Ajayi OC, Muys B. (2011) Integration of legume trees in maize-based cropping systems improves rain-use efficiency and yield stability under rain-fed agriculture. Agricultural Water Management 98, 1364-1372.

Simelton E. (2012) Rice fish in Bac Kan - Practices, challenges and opportunities. Socioeconomic and environmental trade-offs in multi-functional land uses. Field work report. ICRAF Viet Nam.

Sotelo Montes C, Silva DA, Garcia RA, Muñiz GIB, Weber JC. (2011) Calorific value of Prosopis africana and Balanites aegyptiaca wood: relationships with tree growth, wood density and rainfall gradients in the West African Sahel. Biomass and Bioenergy 35:346-353.

Sotelo Montes C, Weber JC. (2009) Genetic variation in wood density and correlations with tree growth in Prosopis africana from Burkina Faso and Niger. Annals of Forest Science 66:713.

Thorlakson T, Neufeldt $H$, submitted. Reducing subsistence farmers' vulnerability to climate change: evaluating the potential contributions of agroforestry in western Kenya. Agricultural Systems.

UNICEF (2007) The state of the world's children 2008. Child survival. The United Nations Children's Fund, New York, USA. 
van Breugel, P. et al. (2011a) Potential Natural Vegetation of Eastern Africa (Ethiopia, Kenya, Malawi, Rwanda, Tanzania, Uganda and Zambia). Volume 6: An Overview of The Methods and Material Used to Develop The Map. Forest \& Landscape, University of Copenhagen (Working Paper 68).

van Breugel, P. et al. (2011b) Potential natural vegetation map of Eastern Africa: Interactive vegetation map for Ethiopia, Kenya, Malawi, Rwanda, Tanzania, Uganda and Zambia. Forest and Landscape (Denmark) and World Agroforestry Centre (ICRAF).

Weber JC, Larwanou M, Abasse TA, Kalinganire A. (2008) Growth and survival of Prosopis africana provenances tested in Niger and related to rainfall gradients in the West African Sahel. Forest Ecology and Management 256:585-592.

Weber JC, Sotelo Montes C. (2010) Correlations and clines in tree growth and wood density of Balanites aegyptiaca (L.) Delile provenances in Niger. New Forests 39:39-49.

WFP (2009) Home grown school feeding: a framework to link school feeding with local agricultural production. World Food Programme, Rome, Italy.

Wulan YC, Budidarsono S, Joshi L. (2006) Economic analysis of improved smallholder rubber agroforestry systems in West Kalimantan, Indonesia - implications for rubber development. Proceedings of the Sustainable Sloping Lands and Watershed Management Conference, 12-15 December 2006. Luang Prabang, Lao PDR, pp. 431-444. Available at:

www.mtnforum.org/en/content/economic-analysis-improved-smallholder-rubber-agroforestrysystems-west-kalimantan-indonesia. 


\section{WORKING PAPERS}

2011

124. An assessment of farm timber value chains in Mt Kenya area, Kenya

125. A comparative financial analysis of current land use systems and implications for the adoption of improved agroforestry in the East Usambaras, Tanzania

126. Agricultural monitoring and evaluation systems

127. Challenges and opportunities for collaborative landscape governance in the East Usambara Mountains, Tanzania

128. Transforming knowledge to enhance integrated natural resource management, research, development and advocacy in the highlands of Eastern Africa

129. Carbon-forestry projects in the Philippines: potential and challenges: the Mt Kitangland range forestcarbon development

130. Carbon forestry projects in the Philippines: potential and challenges. The Arakan Forest Corridor forestcarbon project

131. Carbon-forestry projects in the Philippines: potential and challenges. The Laguna Lake Development Authority's forest-carbon development project

132. Carbon-forestry projects in the Philippines: potential and challenges. The Quirino forest-carbon development project in Sierra Madre Biodiversity Corridor

133. Carbon-forestry projects in the Philippines: potential and challenges. The Ikalahan ancestral domain forest-carbon development

134. The importance of local traditional institutions in the management of natural resources in the highlands of Eastern Africa

135. Socio-economic assessment of irrigation pilot projects in Rwanda

136. Performance of three rambutan varieties (Nephelium lappaceum L.) on various nursery media

137. Climate change adaptation and social protection in agroforestry systems: enhancing adaptive capacity and minimizing the risk of drought in Zambia and Honduras

138. Does value chain development contribute to rural poverty reduction? Evidence of asset building by smallholder coffee producers in Nicaragua

139. Potential for biofuel feedstock in Kenya

140. Impact of fertilizer trees on maize production and food security in six districts of Malawi.

\section{2}

141. Fortalecimiento de capacidades para la gestión del Santuario Nacional Pampa Hermosa: Construyendo las bases para un manejo adaptativo para el desarrollo local. Memorias del Proyect

142. Understanding rural institutional strengthening: A cross-level policy and institutional framework for sustainable development in Kenya 
The World Agroforestry Centre is an autonomous, non-profit research organization whose vision is a rural transformation in the developing world where smallholder households strategically increase their use of trees in agricultural landscapes to improve their food security, nutrition, income, health, shelter, energy resources and environmental sustainability. The Centre generates science-base knowledge about the diverse role that trees play in agricultural landscapes, and uses its research to advance policies and practices that benefit the poor and the environment.

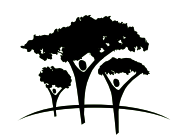

United Nations Avenue, Gigiri - PO Box 30677 - 00100 Nairobi, Kenya

Tel: +254 207224000 or via USA +1 6508336645

Fax: +254 207224001 or via USA +1 6508336646

www.worldagroforestry.org 